\title{
DEVELOPMENT OF INDONESIAN SHARIA BANKS WITH MALAYSIA COMPARATION METHOD (STUDY OF HISTORY, PRODUCTS AND LEGAL ASSETS)
}

\author{
Hagi Hutomo \\ Faculty Of Law, Universitas Negeri Semarang, Semarang \\ hagihutomo@gmail.com
}

\begin{abstract}
Sharia banking is developed in response to economic and cultural groups that are used to accommodate those who want the services to be carried out with Islamic sharia principles and morals. The development of Sharia banks in Indonesia and Malaysia needs to be studied more deeply because Malaysia first established Sharia banks in 1983 through Bank Islam Malaysia Berhad (BIMB) while the first sharia bank in Indonesia, which name of Bank Muamalat, was burned in 1991, which determines the direction of the progress of sharia banks in Indonesia with the provisions of Law Number 10 of 1998 concerning Banking. Determine the amount of assets from banks that have a ratio of 1: 10 with Malaysia considering the assets of sharia banks in Indonesia amounted to US $\$ 35.62$ billion while Malaysia reached US $\$ 423.2$ billion. This study focuses on the factors and effects of legal products from the two countries in order to get more comprehensive study and knowing the relation between the legal products with sharia banking development in Indonesia and Malaysia.
\end{abstract}

Keywords: Islamic Bank; Comparison; Indonesia; Malaysia. 
e-ISSN : 2621-4105

\section{A. INTRODUCTION}

The Bank is a financial institution that has an important role in the economy of a country as a financial intermediary. Bank in Article 1 paragraph (2) Law No. 10 of 1998 concerning amendment to Law No. 7 of 1992 concerning banking is a business entity that collects funds from the public in the form of deposits and distributes it to the public in the form of credit or other forms in order to improve the standard of living of the people. While Islamic Banks are banks that follow the Islamic economic system. As for the Islamic economy according to Fazlurrahman, "Islamic economics according to the builders and supporters are built on or at least colored by the principles of religious, world-oriented and the hereafter." In 1992 Bank Muamalat Indonesia was established as a sign of the dual definition of banks, commercial banks and banks People's Credit in Law Number 10 of 1998 Article 1 concerning banking, namely: "Banks are business entities that collect public funds in the form of deposits and channel them to the public in the form of credit and / or other forms in order to improve the standard of living of the people. While the definition of a commercial bank is a bank that conducts business activities conventionally and / or "based on sharia principles" which in its activities provides services in payment traffic. ${ }^{1}$ Law Number 10 of 1998 Article 1 Paragraph 13 concerning banking states what is meant by sharia principles, namely:

"Sharia principles are rules of agreement based on Islamic law between banks and other parties to deposit funds and or finance business activities, or other activities stated in accordance with sharia, including financing based on profit sharing principles (mudaraba), financing based on equity participation (musyarakah), the principle of buying and selling goods by obtaining profits (mudharabah), or financing capital goods based on the principle of pure choice without choice (ijarah). Or with the transfer of ownership of goods rented from the bank by another party (ijarah wa iqtina) ".

\footnotetext{
${ }^{1}$ Majid, Shabri (2014), Regulasi Perbankan Syariah: Studi Komparatif Antara Malaysia Dan Indonesia, Jurnal Media Syariah, Vol. XVI No. 1, Universitas Syiah Kuala. Page 5.
} 
Whereas in Law Number 21 of 2008 article 1 paragraph 12 concerning Islamic Banking states that what is meant by sharia principles is the principle of Islamic law in banking activities based on fatwas issued by institutions that have authority in determining fatwas in the field of sharia. From the definition of the bank mentioned above, it can be concluded that a Sharia Bank is a business entity that carries out its intermediary function based on sharia principles or in other words the bank in its activities, both fund raising and distribution of funds provides compensation on the basis of sharia principles.

The position of Islamic banks in the law greatly influences the movement of Islamic banks in the country. Islamic banks operating under Islamic banking laws will be more free to operate in sharia compared to Islamic banks operating under banking laws in general. Because of the characteristics of Islamic banks that are typical and different from banks conventionally, Islamic banks will be shackled by their mobility if limited by conventional banking laws. For example, Islamic banks under conventional bank laws may not be allowed to buy and sell goods, it may not be permitted to lease goods, and so on. In fact, Islamic banks are allowed to use a sale and purchase contract (murabahah, salam, or istishna) or rent (ijarah or ijarah muntahiya bittamlik).

Product development policies or approaches chosen by the sharia banking authorities also determine the products and services offered to customers. A product development approach that is careful of Sharia principles will lead to products and services that are always compliant to Shariah principles Syariah in accordance with Sharia principles. Consequently, product development is slower. Conversely, a pragmatic and market driven product development approach will generally lead to a variety of product variations along with similar products in conventional banking. This approach generally adheres to sharia provisions that are more lax, so that the instruments and products produced are creative and innovative following market demand. 
With these differences products, services, and Islamic financial instruments that are available and marketed in one country may not exist and are not offered in other countries because the country's scholars believe that the contract used is not in accordance with Sharia principles in accordance with the schools adopted by the state. or Muslim in the country. For example, the BBA contract (BBA) in Malaysia is not used in the Middle East or in Indonesia, because the BBA uses the Bai 'al-Inah contract in it which is considered by Middle Eastern scholars and Indonesian scholars not in accordance with Sharia principles. These differences make Islamic world products, services and financial instruments very divergent, varied, and have no standards. Therefore international financial institutions such as IFSB (Islamic Financial Services Board) and AAOIFI (Accounting and Auditing Organization of Islamic Financial Institution) are two Islamic financial institutions whose task is to converge, standardize products and operations of Islamic banks internationally. ${ }^{2}$

\section{B. METHOD}

Normative legal research is a type of legal research used in this study. Normative legal research will rely on a method with a focus on library law research using library materials, as well as applicable laws and regulations.

In this legal research a Comparative Approach is used where the comparative approach is carried out by comparing the laws of a country with the laws of one or more other countries regarding the same thing, but it can also be compared in the same law. that is, court decisions in several countries for the same case ${ }^{3}$

Primary legal materials that will be used in the writing, compilation and presentation of this legal research are the legal provisions in the Sharia Banking Act, as well as secondary legal materials related to books, literature, written results of legal experts and doctrines relevant to the discussion on legal research this.

The technique of gathering legal material in this research uses document studies (literature studies). Analysis of primary legal materials and secondary legal materials was carried out by the method of systematic interpretation, then interpreted with the

\footnotetext{
${ }^{2}$ Ibid Page 8.

${ }^{3}$ Peter Mahmud Marzuki. 2010. Penelitian Hukum, Kencana Jakarta: Prenada Media Group, hlm.95
} 
formulation of research problems related to the factors and effects of legal products from the two countries to obtain a more comprehensive study and the relationship between legal products and the development of Islamic banking in Indonesia and Malaysia.

\section{DISCUSSION AND DISCUSSION}

\section{Overview of the Society in Malaysia and Indonesia}

Malaysia is a country that consists of various ethnic groups with diverse religious followers, consisting of Muslims 58\%, Hindus 8\%, Christians 24\% and others $10 \%$. However, the official state religion is Islam. Therefore, the Malaysian government has an obligation to accommodate the development of Islamic financial institutions in Malaysia in accordance with the Islamic religion adopted by the state and the majority of its people. On that basis Malaysia began implementing dual economic systems and developing Islamic financial and banking systems since 1983 .

Indonesia is the largest archipelagic country in the world with diverse ethnicities, languages, and religions with a population of 240 million. Although not an Islamic country, Indonesia is a country with the largest Muslim population in the world with a population of Muslims as much as $88 \%$, Christians 5\%, Catholics $3 \%$, Hindus $2 \%$, Buddhists $1 \%$, and others $1 \%$. With the increasingly advanced financial and banking systems as well as the increasing welfare, the needs of the community, especially Muslims, who want banking services that are in accordance with the principles of Sharia religion that he adheres to become even greater.

\section{Regulation of Sharia Banking in Malaysia and Indonesia}

Islamic banks in Malaysia are under different laws depending on the form of institution. The full Islamic bank (full fledged Islamic bank) is under the Islamic Banking Act issued in 1983. Meanwhile, Islamic windows or conventional banks that offer sharia banking products are under conventional banking laws. With the different laws governing it, full fledged Islamic bank operations are more flexible 
than Islamic windows, especially in the application of Sharia provisions. In addition, the Sharia banking law of 1983 is a civil law so that it remains under the jurisdiction of the civil court. ${ }^{4}$ This situation has implications that although with the Shariah banking law of 1983 Islamic banks can apply Sharia values in their operations, but it is not enough to cover conventional banking laws to reflect the pure concept of buying and selling (al-bai '). In accordance with banking laws, Islamic banks or conventional banks may only provide financing facilities. Banks are not allowed to buy and sell assets for profit. investment banking, merchant banking, leasing company, investment agent, and as an institution of zakat infaq and sadaqah. The difference in operations between BUS and UUS is almost absent except in terms of freedom of management policy. BUS is its own business entity that has policy independence, so it has autonomy in choosing its business strategy and development. Meanwhile, UUS is part of its parent conventional bank, so it lacks the freedom to determine management policies. ${ }^{5}$

Islamic banks in Indonesia, whether in the form of Islamic public banks or BUS (full fledged Islamic banks), sharia business units or UUS (full branch Islamic banks), or sharia people's credit banks or BPRS, are under banking law (Law No .10 of 1998). Banking operations with Sharia principles are fully accommodated by law. Thus, Islamic banks in Indonesia can make transactions based on deposits, loans, for results, buying and selling, leasing, and other principles permitted by Sharia. Thus Islamic banks in Indonesia are universal banks that can try as consumer banking, investment banking, merchant banking, leasing companies, investment agents, and as an institution of zakat infaq and sadaqah amil. The difference in operations between BUS and UUS is almost absent except in terms of freedom of management policy. BUS is its own business entity that has policy independence, so it has autonomy in choosing its business strategy and

\footnotetext{
${ }^{4}$ Ibid Page 10.

${ }^{5}$ Saeed, Abdullah (1999), Islamic Banking and Interest: A study of the Prohibition of Riba and its Contemporary Interpretation, EJ Brill, Leiden. Page 32.
} 
development. Meanwhile, UUS is part of its parent conventional bank, so it lacks the freedom to determine management policies.

3. Differences of Sharia Banking in General Aspects between Malaysia and Indonesia

\begin{tabular}{|c|c|c|}
\hline Issues & Indonesia & Malaysia \\
\hline Population & $\begin{array}{l}240 \text { Million } \\
\text { 88\% Moslem (Syafi'i) }\end{array}$ & $\begin{array}{l}24 \text { Million } \\
58 \% \text { Moslem (Syafi'i) }\end{array}$ \\
\hline State Religion & N/A & Islam \\
\hline $\begin{array}{l}\text { Economic } \\
\text { System }\end{array}$ & $\begin{array}{l}\text { Dual Financial / Banking System } \\
\text { Started in } 1992\end{array}$ & $\begin{array}{l}\text { Dual Financial / } \\
\text { Banking System } \\
\text { Started in } 1983\end{array}$ \\
\hline $\begin{array}{l}\text { Legal } \\
\text { Framework }\end{array}$ & $\begin{array}{l}\text { IBA (1983) under Civil Court } \\
\text { (unable to overrun Banking } \\
\text { Laws) }\end{array}$ & $\begin{array}{l}\text { Banking Act (1992, } \\
\text { 1998) } \\
\text { Islamic Banking Act } \\
\text { (2006 est.) }\end{array}$ \\
\hline $\begin{array}{l}\text { Policy Making } \\
\text { Involvement }\end{array}$ & Mainly Bank Indonesia & $\begin{array}{l}\text { National Agenda } \\
\text { (Government \& } \\
\text { BNM) }\end{array}$ \\
\hline Focus & Substance & Symbol / Form \\
\hline $\begin{array}{l}\text { Development } \\
\text { Paradigm }\end{array}$ & $\begin{array}{l}\text { Market Driven, Fair Treatment, } \\
\text { Gradual \& Sustainable, and } \\
\text { Sharia } \\
\text { Compliance. }\end{array}$ & $\begin{array}{l}\text { Government Driven, } \\
\text { Comprehensive, \& } \\
\text { Pragmatic }\end{array}$ \\
\hline $\begin{array}{l}\text { Development } \\
\text { Stage }\end{array}$ & $\begin{array}{l}\text { Meletakkan Fondasi }(02-04) \\
\text { Memperkuat Struktur }(04-08) \\
\text { International Standards }(08-11)\end{array}$ & $\begin{array}{l}\text { Establish } \\
\text { Infrastructures (83 - } \\
93) \\
\text { Create Critical Mass } \\
(93-00) \\
\text { Global } \\
\text { Harmonization (00 - } \\
10)\end{array}$ \\
\hline
\end{tabular}




\begin{tabular}{|c|c|c|}
\hline $\begin{array}{l}\text { Network } \\
\text { Development } \\
\text { Strategy }\end{array}$ & $\begin{array}{l}\text { Islamic Bank (Full Fledged) } \\
\text { Islamic Branch (Full Branch) } \\
\text { Office Chanelling }\end{array}$ & $\begin{array}{l}\text { Islamic Bank (Full } \\
\text { Fledged) } \\
\text { Islamic Banking } \\
\text { Scheme } \\
\text { Subsidiary bank } \\
\text { Foreign Islamic Bank }\end{array}$ \\
\hline $\begin{array}{l}\text { Sharia } \\
\text { Compliance }\end{array}$ & $\begin{array}{l}\text { Middle East Oriented } \\
\text { Comply to IFA }\end{array}$ & Not Comply to IFA \\
\hline $\begin{array}{l}\text { Sharia } \\
\text { Authority }\end{array}$ & $\begin{array}{l}\text { DSN - MUI as an Independent } \\
\text { Body to issue Fatwa }\end{array}$ & $\begin{array}{l}\text { NSAC Under BNM } \\
\text { \& Merely } \\
\text { issuing Resolution }\end{array}$ \\
\hline $\begin{array}{l}\text { Specific } \\
\text { Contracts }\end{array}$ & $\mathrm{s}$ & $\begin{array}{l}\text { Bai' al-Dayn, Bai' al- } \\
\text { Inah, BBA }\end{array}$ \\
\hline $\begin{array}{l}\text { Financing } \\
\text { Portfolio }\end{array}$ & Varied with $33 \%$ PLS & $\begin{array}{l}\text { Focused on BBA \& } \\
\text { Murabahah } \\
\text { with only } 0.05 \% \text { PLS }\end{array}$ \\
\hline $\mathrm{NPF}$ & Less than $5 \%$ & Reach $10 \%$ \\
\hline Asset Share & $1.34 \%$ (started from 1992) & $\begin{array}{l}+/-9 \% \text { (Started from } \\
1983)\end{array}$ \\
\hline
\end{tabular}

Table $1^{6}$, in a comparative analysis of the application of sharia principles to Malaysian and Indonesian Islamic banks, Malaysian banks implemented products based on the principles of Bai 'al-Inah and Bai' al-Dayn which were not approved by the Islamic Fiqh Academy (IFA), while Indonesian banking was in line with the IFA, namely do not apply these two principles.

Comparing Indonesian and Malaysian banks must also pay attention to environmental conditions in both, for example the Malaysian environment which is more concerned with the symbolization of the implementation of Islamic practices,

${ }^{6}$ Abd. Majid, M.S. and Amri, 2010. Perbankan syariah di Indonesia: Antara tantangan dan harapan, Jurnal Perspektif Manajemen dan Perbankan, Vol. 1, No. 2. Page 53. 
meaning more attention to symbolic issues than the issue of the substance of the application of Islamic banking that adheres to sharia principles. This is related to the Muslim population which is relatively not dominant so that the implementation of Islamic practices becomes a representation of maintaining the existence of Muslim society, so that attention to the compliance of Islamic principles is still not the main focus. On the contrary, what happened in Indonesia, with a population that was so dominant and the demands of the Muslim community who hoped for banking operations in an ideal form, Islamic banking oparational must pay attention to the substance, especially operational compliance with sharia principles. From one side this is seen as a positive trend, because there has been supervision by the community. Besides that the development of Islamic banking in Malaysia is a national agenda, in contrast to Indonesia where the development of Islamic banking is dominated by Bank Indonesia initiatives. In the development of Malaysian Islamic banking it is seen that the issue of sharia compliance is relatively less of a concern. This should be a competitive advantage for the Indonesian Islamic banking industry, where in the development of the sharia banking industry in Indonesia, compliance with sharia principles is one of the basic considerations in industrial development. This advantage can be used as a strong capital in promotion to attract foreign investors (especially the Middle East who are currently enjoying petro dollars due to the increase in world crude oil prices). Meanwhile, financing channeled by Malaysian Islamic banking is dominated by Bai 'Bithaman Ajil (BBA) and Murabahah portfolios where the share of the share of profit sharing is only $0.05 \%$. On the contrary, the financing portfolio in Indonesian Islamic banking is relatively varied, where the profit sharing portfolio reaches $33 \%$.

\section{Sharia Banking Development Strategy in Malaysia and Indonesia}

The long-term goal to be achieved in the development of Islamic banking in Malaysia is to create a comprehensive Islamic financial and banking system that operates parallel to the conventional banking system. To create a strong banking 
system, three important elements are needed, namely: 1) a large number of players; 2) wide variety of instruments; and 3) Islamic money market. The chosen development strategy is the development of a comprehensive, gradual, and pragmatic, which begins with the stages to create an enabling environment by preparing various financial infrastructure, especially the legal framework. The next stage is to increase the volume and create a market for Islamic financial institutions so that Islamic financial institutions can compete. The third stage is to create harmonization and convergence with the international Islamic financial market so that Malaysian Islamic financial institutions can compete internationally.

The first phase of development began with the issuance of the Islamic Banking Act (IBA) on April 7, 1983. With the promulgation of the IBA, Bank Negara Malaysia (BNM) was authorized to regulate and supervise Islamic banks, as well as conventional banks. The first Islamic bank was Bank Islam Malaysia Berhad (BIMB) which began operations on July 1, 1983 with a total asset of RM 369.8 million or equivalent to Rp. 1,035 trillion (RM 1 = Rp. 2,800). In 1983 a Government Investment Act (GIA) was also issued which authorized the government to issue Government Investment Issues (GII) which were securities issued by the government based on Sharia principles. GII is a form of Islamic financial instruments needed for the management of Islamic bank liquidity needs.

After that, in 1984 the Takaful Act was issued which became the legal foundation of sharia insurance to operate as one of the supporting infrastructure for Islamic banking. The first Islamic insurance company was Syarikat Takaful Malaysia which was established that same year. Other provisions issued in this first stage are the obligations of banks and sharia insurance to have a Sharia Supervisory Board whose task is to ensure that operations and banking and sharia insurance products are in accordance with Sharia provisions.

The second phase of development began on the fourth of March 1993 by introducing the "Free Banking Scheme" or SPTF (Interest Free Banking Scheme).

\footnotetext{
${ }^{7}$ Bank Islam Malaysia Berhad, 1994. Islamic Banking Practice from Practitioner's Perspective, Kuala Lumpur. Page 93.
} 
With this scheme conventional banks are allowed to offer Islamic banking products, or commonly called Islamic Windows. With this strategy the number of bank offices offering Sharia products is increasing rapidly effectively and efficiently because the sharia banking service outlets have increased in a short time as many existing bank office networks and conventional financial institutions are initiated by three banks and 54 financial institutions as pilot projects. In the following year, in 1994, the Islamic Interbank Money Market was established on January 4 to connect Islamic financial institutions through Sharia money market instruments, which also became a milestone in the development of Islamic financial instruments. Meanwhile, the sharia capital market followed in 1996 which encouraged the development of Sharia securities. In an effort to smooth and harmonize interpretations of Sharia provisions, a Sharia Advisory Board for Islamic Banking and Insurance was established on May 1 (National Sharia Advisory Council on Islamic Banking and Takaful or NSAC), as the highest Sharia authority in banking and sharia insurance. in Malaysia. In addition, during this second phase of development, the second Islamic bank was established on October 1, 1999, namely Bank Muamalat Malaysia Berhad or BMMB, and three Islamic insurance companies were granted an operating license, namely Takaful National Sdn. Berhad, Maybank Takaful Berhad, and Takaful Ikhlas Sdn. Berhad. The third phase of development begins with the creation of the FSMP Financial Sector Master Plan in 2000 for the period 2000 - 2010 which covers the Islamic finance sector. FSMP for sharia banking and insurance is divided into three phases, namely: 1) Strengthening operational and institutional infrastructure; 2) Stimulate competition and improve infrastructure; and 3) Improve performance standards through progressive liberalization and ensure effective infrastructure. To support FSMP, a review of the Islamic Windows strategy was carried out which still caused debate about its compliance with Sharia provisions and issued provisions in 2004 to encourage Islamic Windows to transform into an Islamic Subsidiary. In the same year liberalization of banking and sharia insurance was carried out by issuing permits for 
three foreign sharia financial institutions and four Takaful with the participation of foreign parties. In addition, at this stage efforts were also made to: 1) improve regulatory, prudential and operational frameworks; 2) review return to the legislative process and the court; 3) developing the Sharia governance framework by establishing the National Shariah Advisory Council at BNM and Shariah Committees in Islamic financial institutions; and 4) forming endowment funds for sharia experts to support their

role.

On the basis of encouraging community needs for Islamic banking services, the first Islamic bank was established in 1992 and the Indonesian government began introducing the dual banking system. The Government's commitment in the development of sharia banking has only begun to be felt since 1998 which provides wide opportunities for Islamic banks to develop. The following year Bank Indonesia (the central bank) was given the mandate to develop Islamic banking in Indonesia. In addition to adhering to a market driven and fair treatment strategy, the development of Islamic banking in Indonesia is carried out with a gradual and sustainable approach in accordance with Sharia principles (comply to Sharia principles). The first stage was intended to lay the foundation for a strong growth of Islamic banking (2002 - 2004). The next phase enters a phase to strengthen the structure of the Islamic banking industry (2004 - 2008). Meanwhile, the third stage of Islamic banking is directed to be able to meet international financial and service quality standards (2008 - 2011). In 2011, it is expected that Indonesian Islamic banking has a significant share that will take part in developing the Indonesian economy which will prosper the wider community.

\section{Comparison of Products}

Islamic banking products and services in Malaysia vary greatly to more than 40 types of sharia financial products and services using various contracts. These products and services include products and services for funding, financing, trade finance, banking services, card services, card services, and treasury and money market 
instruments. These products and services are very similar to the products and services offered by conventional banking. The naming of sharia products and services follows the name conventional products and services by adding the initials $\mathrm{i}$ behind which indicate that the product or service is a product or service that uses sharia principles (Islamic). For example, savings or savings accounts are named savings account-i, project financing or project financing is named project financing-i. So on.

\section{Regulations Malaysian Sharia Banking}

Moeslem is the official religion in Malaysia. This is as stated in Federal Constitution Article 3 (a) which quotes: "Moeslem is a federation religion; But other religions can also be peaceful and dangerous in the state ".

Sharia banking in Malaysia under the auspices of the Central Bank, BNM adopts a dual banking system, whereSharia banking operates side by side with conventional banking. As a central bank, BNM holds full authority to control and regulate banking operations in the country. Similar to conventional banks, Islamic banks are also under the supervision and regulation of BNM, as an authoritative body that has the right and comprehensive legal force to regulate and supervise the financial system in Malaysia based on the Central Bank of Malaysia Act 1958

in principle,Sharia banking operations in Malaysia have two main legal bases, namely Sharia banking Act (IBA) 1983, and the Banking and Financial Institutions Act (BAFIA) 1989. IBA 1983 specifically regulates Islamic banks where Islamic teachings can be applied in the banking business. This law does not contain provisions relating to any banking business, or evenSharia banking business carried out by conventional banks. The birth of this Act has opened the way for the formation of Islamic banks in Malaysia. In contrast, the 1989 BAFIA was enacted to regulate conventional banks, including those operating Sharia banking business in addition to the interest-based business. This Act is actually an amalgamation of two existing legal products, namely the Financial Companies Act 1969 and the 1963 Insurance Act. The birth of BAFIA 1989 has provided a legal basis for financial institutions to carry 
outSharia banking business under certain conditions. The only provisions of Sharia banking business carried out by conventional banks are regulated in article 124 (1) which states:

"Except as provided in section 33, nothing in this Act or Sharia banking Act 1983 prohib prohibit or restrict any licensed institution consult the bank before it carries onSharia banking business or any Islamic financial business. " sharia and conventional banks that are not covered by the above Act, it is regulated in other relevant laws and someSharia banking guidelines issued by BNM.

\begin{tabular}{|c|c|c|}
\hline Regulation & Sharia Banking & Conventional Banking \\
\hline $\begin{array}{l}\text { Companies Act } 1965 \\
\text { Central Bank Act } \\
\text { (CBA 1958) }\end{array}$ & $\begin{array}{l}\text { Establishment } \\
\text { Sharia Formation Advisory } \\
\text { Council (SAC) }\end{array}$ & $\begin{array}{l}\text { Establishment } \\
\text { Sharia Formation } \\
\text { Advisory Council (SAC) }\end{array}$ \\
\hline $\begin{array}{l}\text { Islamic Bank Act } \\
\text { (IBA 1983) }\end{array}$ & $\begin{array}{l}\text { Licence } \\
\text { Supervision } \\
\text { Management } \\
\text { Sharia establishment }\end{array}$ & \\
\hline $\begin{array}{l}\text { Banking and Financial } \\
\text { Institutions Act (BAFIA) } \\
1989\end{array}$ & & $\begin{array}{l}\text { Licence } \\
\text { Supervision } \\
\text { Management }\end{array}$ \\
\hline $\begin{array}{l}\text { Guidelines on skim } \\
\text { Banking without benefits } \\
\text { (SPTF) } 1993\end{array}$ & & $\begin{array}{l}\text { Islamic Banking } \\
\text { Business Products } \\
\text { Requirements and } \\
\text { Procedure for } \\
\text { Establishing IBU } \\
\text { (Islamic Banking Unit ) }\end{array}$ \\
\hline $\begin{array}{l}\text { Guidelines on } \\
\text { the Governance } \\
\text { of Shariah } \\
\text { Committee for the } \\
\text { Islamic Financial } \\
\text { Institutions (BNM/ } \\
\text { GPS1) } 2004\end{array}$ & $\begin{array}{l}\text { Duties and responsibilities } \\
\text { Haria Replied Committee }\end{array}$ & $\begin{array}{l}\text { Duties and } \\
\text { responsibilities Haria } \\
\text { Replied Committee } \\
\text { members }\end{array}$ \\
\hline
\end{tabular}




Cental Banking Act
(CBA 2009)

Table 2. Regulations Malaysian Sharia Banking

\section{Regulations Indonesia Sharia Banking}

BNM Authority to make

Malaysia as International

Islamic Financial Hub.

Sharia banking regulations eventually narrowed to Law No. 21 of 2008 concerning Islamic Banking. In conducting sharia banking business activities, Indonesian sharia banks must be guided by sharia principles. The Sharia principle referred to in this Law is stipulated in Article 1 number 12, which is "the principle of Islamic law in banking activities based on fatwas issued by institutions that have the authority to determine fatwas in the field of sharia". The principles of Islamic law which form the basis of the implementation of Islamic banking activities are determined that there is a fatwa prepared by the authorized institution. Regarding the institution authorized to issue a fatwa, it can clearly be seen in the provisions of Article 26

\begin{tabular}{|l|l|l|}
\hline \multicolumn{1}{|c|}{ Regulation } & \multicolumn{1}{|c|}{ Sharia Banking } & Conventional Banking \\
\hline $\begin{array}{l}\text { Law No 21 (2008) concerning } \\
\text { Sharia Bank }\end{array}$ & $\begin{array}{l}\text { Licence } \\
\text { Prudent Supervision } \\
\text { Management } \\
\text { Transver of convensional } \\
\text { to sharia bank } \\
\text { Punishment \& Law }\end{array}$ & \\
\hline $\begin{array}{l}\text { UU No. 23 (1999) } \\
\text { About Bank Indonesia }\end{array}$ & $\begin{array}{l}\text { Bank Indonesia must } \\
\text { support the sharia bank } \\
\text { business }\end{array}$ & $\begin{array}{l}\text { Bank Indonesia must } \\
\text { support the sharia } \\
\text { bank business }\end{array}$ \\
\hline $\begin{array}{l}\text { BINo Regulation. 624 / PBI/ } \\
\text { 2004 concerning Banks } \\
\text { Commercial ones doing } \\
\text { Sharia business principles }\end{array}$ & $\begin{array}{l}\text { Requirements \& } \\
\text { Procedures for } \\
\text { establishing legal } \\
\text { products } \\
\text { Products }\end{array}$ & \\
\hline
\end{tabular}




\begin{tabular}{|c|c|c|}
\hline $\begin{array}{l}\text { Amended inside BI } \\
\text { Regulation No. } 735 \text { / PBI/ } \\
2005\end{array}$ & $\begin{array}{l}\text { Board Formation } \\
\text { Sharia Advisors }\end{array}$ & \\
\hline $\begin{array}{l}\text { BIRegulation No. } \\
\text { 83/PBI/2006 } \\
\text { About Business transfer } \\
\text { Comercial Bank Convention } \\
\text { to the Bank Comercial ones } \\
\text { doing business Sharia } \\
\text { principles and founders haria } \\
\text { Advisors } \\
\text { Conventional Commercial } \\
\text { Bank }\end{array}$ & $\begin{array}{l}\text { Requirements \& } \\
\text { Procedures Formation / } \\
\text { Transfer } \\
\text { Products } \\
\text { Products }\end{array}$ & \\
\hline $\begin{array}{l}\text { BI Regulation No 7/46/ } \\
\text { PBI/2005 concerning Funf } \\
\text { mobilization and financing } \\
\text { Agreement for Business Bank } \\
\text { Sharia Principles }\end{array}$ & $\begin{array}{l}\text { Contract requirements } \\
\text { deep financial } \\
\text { agreement banking } \\
\text { business sharia }\end{array}$ & $\begin{array}{l}\text { Contract requirements } \\
\text { deep financial agreement } \\
\text { banking business sharia }\end{array}$ \\
\hline $\begin{array}{l}\text { Circular No. } \\
\text { 8/19/DPBS All Commercial } \\
\text { Banks who carry out Sharia } \\
\text { business principles, Islamic } \\
\text { supervision \& Report results } \\
\text { guide Advisor board sharia }\end{array}$ & $\begin{array}{l}\text { Duties \& } \\
\text { Responsibilities replied } \\
\text { the member board of } \\
\text { trustees sharia and } \\
\text { activity sharia } \\
\text { supervision }\end{array}$ & $\begin{array}{l}\text { Duties \& } \\
\text { Responsibilities replied } \\
\text { the member board of } \\
\text { trustees sharia and } \\
\text { activity sharia } \\
\text { supervision, }\end{array}$ \\
\hline
\end{tabular}

Table 3. Regulations Indonesia Sharia Banking

\section{CONCLUSION}

There is a difference in the level of development of the Islamic banking industry between Malaysia and Indonesia due to the different approaches adopted by each country in providing a legal response to the emergence of Islamic banking. Islamic banking regulations in Malaysia have been very adequate even since the first Islamic bank (BIMB) appeared. Whereas in Indonesia, after 16 years the first Islamic bank (BMI) operated, the new Islamic banking regulation was promulgated. The elimination of double taxes and the settlement of sharia business disputes has only been set up since 2010. Though this 
regulation has been established in Malaysia before BIMB was born. Unlike in Indonesia, in fact the Malaysian government has previously established regulations on Islamic banking before the first Islamic banking was established in 1983. Whereas in Indonesia, the regulation only emerged after 16 years the Islamic bank operated. This difference has affected the rate of growth and development of Islamic banking in each country. Islamic banking in Malaysia has shown steady and fast progress compared to Indonesia.

\section{REFERENCES}

\section{BOOKS}

Rosly, Saiful Azhar (2005), Critical Issues on Islamic Banking andFinancial Markets, Dinamas Publishing, Kuala Lumpur, Malaysia.

Saeed, Abdullah (1999), Islamic Banking and Interest: A study of the Prohibition of Riba and its Contemporary Interpretation, EJ Brill, Leiden.

Ascarya (2006), Comparing Islamic Banking Development in Malaysia and Indonesia: Lessons for Instruments Development, Center for Central Banking Education and Studies Bank Indonesia.

Peter Mahmud Marzuki. 2010. Penelitian Hukum, Kencana Jakarta: Prenada Media Group

Bank Islam Malaysia Berhad, 1994. Islamic Banking Practice from Practitioner's Perspective, Kuala Lumpur.

\section{JOURNAL}

Abdul Majid, M.S. and Amri, 2010. Perbankan Syariah di Indonesia: Antara Tantangan Dan Harapan, Jurnal Perspektif Manajemen dan Perbankan, Vol.1, No. 2.

Anshori, A. S., 2008. Sejarah Perkembangan Hukum Perbankan Syariah di Indonesia dan Implikasinya bagi Praktik Perbankan Nasional, La Riba: Jurnal Ekonomi Islam, Vol. II, No. 2.

Majid, Shabri (2014), Regulasi Perbankan Syariah: Studi Komparatif Antara Malaysia Dan Indonesia, Jurnal Media Syariah, Vol. XVI No. 1 , Universitas Syiah Kuala, Banda Aceh. DOI: http://dx.doi.org/10.22373/jms.v16i1.1758 